\title{
NATIONAL SECURITY EXCUSE FOR THE NEO-PROTECTIONIST TRADE POLICY OF PRESIDENT'S TRUMP ADMINISTRATION
}

\author{
Ryszard ŁAWNICZAK
}

Wojskowa Akademia Techniczna

\begin{abstract}
In March 2018, the newly elected President of the United States, Donald Trump, surprised the world by triggering a trade war with his largest trading partners. He announced that he would introduce $25 \%$ and $10 \%$ of customs tariffs on imports of steel and aluminium. Besides he threatened to impose duties on imports of European cars, as well as on the entire list of other products, as long as the trading partners do not stop unfair trading practices and will not reduce their own barriers to American products. In the article, the author tries to explain why protectionist measures of the American administration should be defined as "neo-protectionism", and why and if justly those protectionist steps President Trump justifies as a "threat to national security".

Keywords: neo-protectionism, "threat to national security", tariffs, trade war.
\end{abstract}

\section{Introduction}

The United States President Trump shocked the world in 2018 by undermining the global order in the field of international trade. It was based on the conviction that the liberalization of international trade through multilateral negotiations, aimed at reducing customs tariffs and other barriers, will contribute to economic growth and increase the level of prosperity of all countries participating in this process.

This liberalization process has taken place mainly within the framework of the GATT (General Agreement on Tariffs and Trade), international organization specially devised for this purpose. GATT was later (1995) transformed into the World Trade Organization (WTO). The main actions aimed at liberalizing the international trade (but only of industrial products) were the so-called Rounds of Negotiation. One of the most important of them: the so-called "The Kennedy Round" (1964/1967), brought a reduction of customs tariffs on the industrial products an average of $25-40 \%$.

The end of the 1960s and the beginning of the Seventies brought, however, the return of the first wave of protectionism in the United States policy. (see below) However this kind of protectionism, performed by highly developed countries, is not the "justified" protectionism, aimed at protecting "the infant industry" of newly emerging economies of developing countries, but "NEO-PROTECTIONISM"1 or

R. Ławniczak, Bariery pozataryfowe: narzędzia polityki handlowej i neoprotekcjonizmu lat siedemdziesiątych, Akademia Ekonomiczna (Zeszyty Naukowe - Seria II), Poznań 1975, p. 31. 
"NEO-MERCANTYLISM". This version of protectionism, of highly developed countries, is aimed at maintaining high profits of their corporations and domination in the global economy. As one of the Indian economist rightly confirms: "...developed countries are using these measures lavishly to restrict imports from developing world. Hence the use of these instruments in an unfair manner is called as neo-protectionism or new protectionism by developing countries". ${ }^{3} \mathrm{Neo}-$ protectionism of President Trump represents just another stage of this phenomenon.

The aim of the article is to explain the reasons for the return in US neo-protectionist trade policy of President Trump. From the end of the Second World War, the U.S. promoted free trade and a system of free market economy. Ever since Donald Trump resided with the President, there has been a sudden shift in US trade policy toward "Neo-protectionism". Trump's administration justifies the reasons for this return mainly due to the "threats to national security". Another goal which the author sets himself, is to analyze the truth of the argument "threat to national security" as the official justification for such a policy, as well as the possible consequences of such policy from the point of view of further development of world trade.

This article is limited only to the neo-protectionist trade policy with reference to the "national security threats". The same "national security threats" argument has already been used in the foreign economic policy of the United States to limit foreign direct investment (FDI). The activities of the specially appointed for this purpose interagency "Committee on Foreign Investment in the United States" (CFIUS) have already been analyzed by the author in an earlier publication. ${ }^{4}$

\section{The short history of American protectionism}

\subsection{Justified protectionism with "infant industry" argument}

Trump is not the first protectionist President in the American history. In fact, the United States has a long history of protectionism, starting from the earliest days of the American republic. It was Alexander Hamilton, the country's first treasury secretary, who could be called „the father" of America's original protectionism. Being at that time the British colony, the U.S. was banned by Britain from importing anything that would enable them to build an industrial economy.

2 H.G. Johnson, Mercantilism: Past, Present and Future, Journal of World Trade Law 1974, No. 1, pp. 10-16.

3 J. Tojo, What is neo (new) protectionism under WTO? January 6, 2017.IndianEconomy.net. Retrieved from: https://www.indianeconomy.net/splclassroom/

4 R. Ławniczak, "National Security Implication of foreign direct investments within the framework of Reverse Globalization", Studia Bezpieczenstwa Narodowego, Rok III, Nr 4, pp. 339-362. 
After the U.S. have gained its independence, Hamilton in his famous "Report on Manufactures," presented to the Congress the classic ,infant industry argument". Until today, this argument states that for an economy on a lower level of economic development, with primary agricultural structure, it is necessary to raise tariffs on imported products from superior industrially developed countries. This way it should to protect their developing infant industries, and changing their economic structure from agriculture dependent to industrialized economy. ${ }^{5}$ As a result, according to Chang, "Between 1816 and the end of the Second World War, the U.S. had one of the highest average tariff rates on manufacturing imports in the world".

\subsection{Protectionism in the times of crisis}

Protectionist measures are often applied by governments, not only American, in the times of economic crises to boost domestic employment, protect the living standards of the ordinary people, and offer the government argument that it is taking care of its electorate. Nothing else happened in the US when president Hoover, who campaigned on protectionist ticket, has accepted the Smoot-Hawley Tariff in 1930. An average of $40 \%$ tariff was levied on over 20 thousands items creating a kind of tariff wall lasting until the years after the Second World War.

\subsection{Neo-protectionism of "fair trade" argument}

The beginning of seventies has brought the first signs of a relative decline in the U.S. international economic position in the world. For example, in 1967, the United States lost the position of the world's largest exporter to the EEC. Additionally in 1971 Germany overtook the U.S. also, taking first place in terms of the size of reserves of gold and convertible currencies.

In such circumstances, to help the United States industry to become more competitive toward the Japanese and/or German products, The Trade Act of 1974 was enacted. This Act authorised the President to negotiate trade agreements which Congress could only approve or disapprove, but had no authority to amend or filibuster. The Act provided also the President with tariff and non-tariff trade barrier negotiating authority for the multilateral trade negotiations.

The highly important Section 301 of this Trade Act (last edition added by Trump administration on March 23,2018) provides "the United States with the authority to

5 The same argument was presented by the Friedrich List, which enabled Prussia's industrialisation. See: F. List, The National System of Political Economy, J.B. Lippincott \& Co., Philadelphia 1856.

6 Ha-Joon Chang, Kicking Away the Ladder: The "Real" History of Free Trade, FPIF Special Report, December 2003.

7 Ha-Joon Chang, Bad Samaritans: The Myth of Free Trade and the Secret History of Capitalism, London 2008. 
enforce trade agreements, resolve trade disputes, and open foreign markets to U.S. goods and services. It is the principal statutory authority under which the United States may impose trade sanctions on foreign countries that either violate trade agreements or engage in other unfair trade practices." (Emphasis added).

This Trade Act 1974 opens the first stage of American Neo-protectionism. That type of protection of national industries can't be any longer justified by the Hamilton's "infant industry argument", because in the seventies U.S. is the world political and economic super-power No. 1. At that stage, the interpretation that imports enter the U.S. because of "unfair trade practices" by the competitors depends fully from American administration, end is often misused. In the opinion of American expert "Congress reacted by adopting the Trade Act of 1974, because industry after industry has appealed for help against foreign competition, even as it turns to new manufacturing techniques to eliminate jobs".

\section{The specifics and goals of the new stage of the American neo-protectionism of the era of President Trump}

It may be difficult, for an average citizen, to understand why the United States, which neoliberal economists and politicians promoted free trade and the free market economy for years, suddenly make a sudden turn towards the next stage of neo-protectionism. Simplifying the matter, one can say that it explains the phrase password "Let's make America Great Again", under which Trump won the election. The American president assumed that by undermining the principles of the post-war world economic order, he would succeed -through bilateral relations, (Emphasis added) and from the position of strength, to restore the dominant position of the United States in the global economy. This post-war system was based on multilateral agreements and organizations such as: GATT / WTO, NATO, European Union, North-American American Free Trade Agreement (NAFTA), etc.

\subsection{New stage of the American Neo-protectionism}

We are talking here about the most recent stage (from March 2018) of the American policy of neo-protectionism after the Second World War. (Emphasis added). The first stage of such a policy (see above) occurred already at the turn of the sixties and seventies. Since then, the neo-protectionism of the rich, highly developed industrialized countries, has three characteristics:

- it is selective (as opposed to covering the majority of imported goods);

8 D.A. Irwin, Clashing Over Commerce: A History of US Trade Policy, Chicago, University of Chicago Press, 2017. 
- regional (connected with the creation of regional integration groups and preferential agreements);

- non-tariff, due to the decline in the importance of tariff barriers, after subsequent rounds of customs negotiations under GATT.

The recent German study of $2017^{9}$ confirms that by stating: “...tariffs are not the major tool for countries to protect domestic economies. Instead, non-tariff barriers are most often applied. Since 2009 , only $20 \%$ of all implemented protectionist interventions can be attributed to an increase in tariffs. In contrast, non-tariff barriers accounted for on average $55 \%$ of the implemented protectionist interventions". "The United States implemented by far the largest number of non-tariff barriers. With close to 800 non-tariff barriers the US government implemented twice as much protectionist policies as the Indian government, which ranks second."

\section{Once highly protective, U.S. tariffs are much lower today}

Duties as a share (\%) of the total value of __, 1821-2017

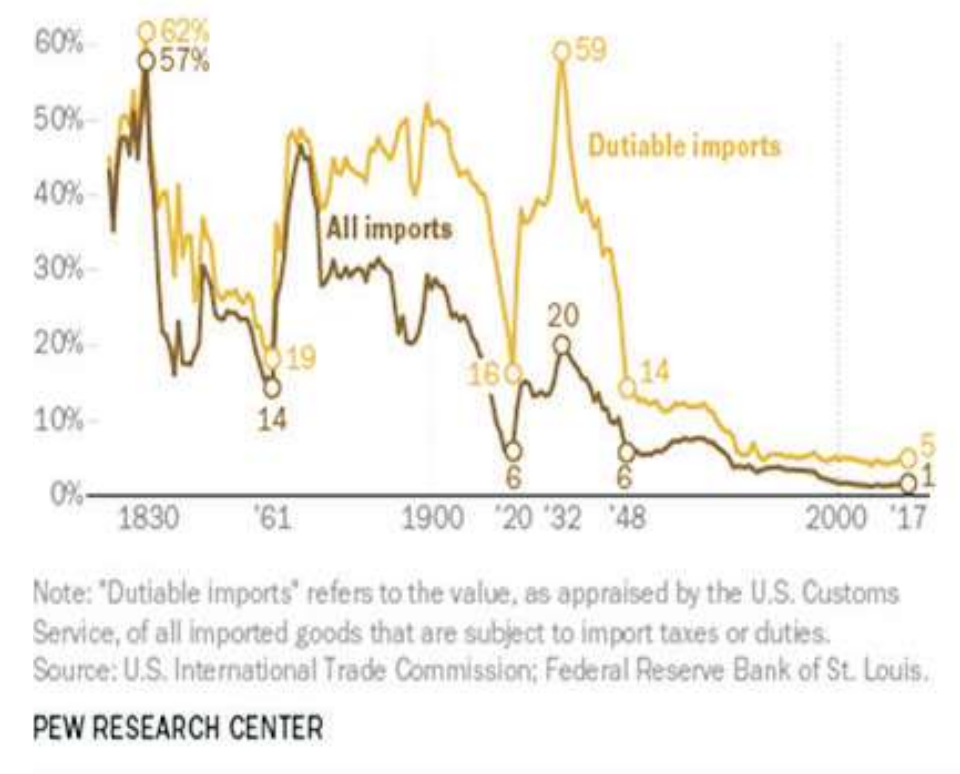

Fig. 1

9 E. Yalcin, G. Felbermayr, L. Kinzius, Hidden Protectionism: Non-Tariff Barriers and Implications for International Trade, ifo Institut, Munchen 2017, p. 8. 
Considering, however, that in parallel with its highest level of non-tariff protectionism in the world today, the United States uses one of the lowest tariffs (as shown in the chart above), it is worth asking why the Trump administration has just applied customs tariffs as a tool to improve the US trade balance. The "BBC News"10 (online edition) tries to explain it as follows:

- Mr Trump made a big point on the campaign trail about cutting the country's trade deficits. He's convinced it hurts US manufacturing;

- the US has a massive trade deficit with China. Last year, it stood at about $\$ 375$ bn. Mr Trump's not happy about that;

- At the start of March, the President announced a 25\% tariff on all steel imports, and $10 \%$ on aluminium. The Trump administration claims the US relies too much on other countries for its metals, and that it couldn't make enough weapons or vehicles using its own industry if a war broke out;

- Taxing foreign steel and aluminium will mean US companies will buy local steel instead. The thinking is that will boost the US steel and aluminium industries, as more companies will want to buy their goods.

Both the theory of international trade and the voices of representatives of American industry, terrified by the potential effects of a trade war, indicate that the choice of tariff barriers as a tool for improving the American payment balance is at least doubtful. The imposition of duties on, for example, raw materials such as steel or aluminum causes an increase in prices and inflation in the country that imposes them; thus limits exports of more expensive products in this way; the effect of duties is also easily neutralized by manipulating the exchange rate. In addition, customs barriers can easily be "jumped over" by transferring production to the country that uses them. Long time ago, many Japanese, German and now also Chinese companies have done so.

In spite of the above presented opinion, according to President Trump: "Tariffs are the greatest! Either a country which has treated the United States unfairly on Trade negotiates a fair deal, or it gets hit with Tariffs," the president wrote on Twitter. ${ }^{11}$ Therefore, it should be assumed that the threat of imposing imported products with tariffs as high as $25 \%$ has been chosen by Trump as an "economic blackmail" used as a negotiation tool, to enforce concessions from trade partners. What was already confirmed by the first weeks of bilateral negotiations in trade relations with Mexico and Canada, and in July 26, 2018 also with the European Union, after the meeting Trump-Junker.

10 BBC NEWS (online edition), June 15, 2018.

11 POLITICO, July 25, 2018. 


\subsection{The doubtful "national security" excuse}

Although Trump is accused of sidestepping the multilateral rules-based trading system, in some ways, Washington is adhering to WTO guidelines, which have a build-in loophole in there articles. "Article XXI" of the WTO's General Agreement on Tariffs and Trade allows namely for the levying of import duties, among others - for reasons of national security, and this is exactly the official excuse the US is officially using.

The above mentioned loophole in the GATT Article XXI is known as the "National Security Exception". The key to that loophole, is according to American expert ${ }^{12}$ that "It permits members to impose trade restrictions for purposes of national security without obligating them to demonstrate that their rationale confirms with some agreed definitions of national security or national security threats".

Early March 2018 the US administration have announced the package of steel and aluminum tariffs by deploying an seldom-used the 1962 Trade Expansion Act. This act gives the President unilateral power to act to restrict trade that threatens "national security". Particularly important is the Section 232 of the Act. It authorizes the Secretary of Commerce to decide if some imports of specific goods may have "deleterious effect on national security". It may occur in following situations: ${ }^{13}$

- Domestic production needed for projected national defense requirements;

- Domestic industry's capacity to meet those requirements;

- Related human and material resources;

- The importation of goods in terms of their quantities and use;

- The close relation of national economic welfare to U.S. national security;

- Loss of skills or investment, substantial unemployment and decrease in government revenue; and

In the opinion of French expert: ${ }^{14}$ "However rather than believing that Trump's tariffs seek to protect US industries that are vital to the country's defense, one should see them as "leverage to win additional economic gains from the U.S. biggest trading partners and preserve high profits for American business."

12 D. Ikenson, The Danger of Invoking National Security to Rationalize Protectionism, China-United State Exchange Foundation, May 15, 2017. Retrieved from: https://www.chinausfocus.com/peacesecurity/

13 Quoted after: P. Mints, Why a Misuse of the Trade Expansion Act of 1962 Could Lead to Higher Costs for US Solar Projects, RENEWABLE ENERGY WORLD, February 27, 2018.

14 D. Beazley, Trade-and-national-security-risks, NATIONAL, April 23, 2018. Retrieved from: http:// nationalmagazine.ca/Articles/April-2018/.aspx 


\section{The response of most important trading partners}

The table below presents the list of the most important trading partners of the US and the scale of the trade deficit, which president Trump tries to reduce, if not eliminate, by applying his aggressive neo-protectionist policy.

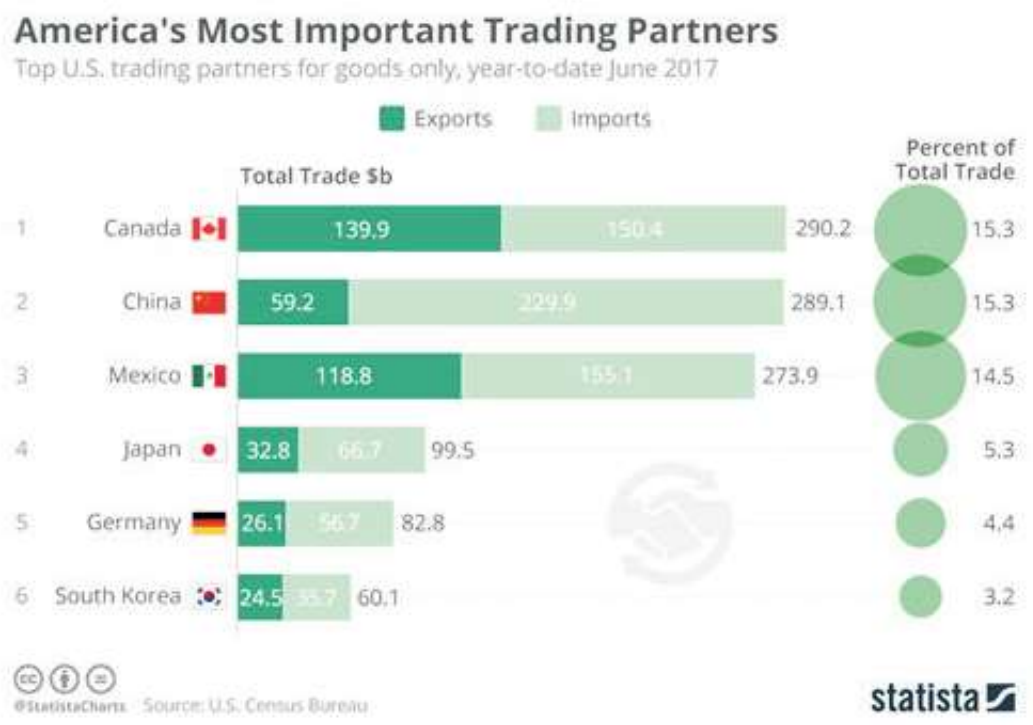

Fig. 2

\subsection{Closest neighbours: Canada and Mexico}

The trade relations with the closest U.S. neighbours: Canada and Mexico are since 1994 regulated by the free trade agreement NAFTA (North-American Free Trade Agreement). In spite of that agreement, on March 1, 2018 Trump have repeated his determination to push ahead with a 25 per cent tariff on steel imports and a 10 per cent duty on aluminium. "We have large trade deficits with Mexico and Canada. NAFTA, which is under renegotiation right now, has been a bad deal for USA Massive relocation of companies \& jobs. Tariffs on Steel and Aluminium will only come off if new \& fair NAFTA agreement is signed," Trump tweeted on Monday. March 5th, 2018.

So far (the end of July 2018) Mexico and Canada have so far pushed back against the toughest U.S. demands during a half-dozen rounds of talks to update NAFTA. After the July round of negotiations, U.S. Trade Representative was not to report news suggesting the three sides were getting closer to resolving many of their differences. 


\subsection{China}

China is the U.S. second largest trading partner against which the president Trump decided to announce a trade war. Until the end of July 2018 the US administration has imposed billions of dollars in tariffs on China. The main reasons: accusation of applying unfair trade practices, intellectual property theft as well as forced technology transfers. Last week of July 2018 the President announced additionally that he is prepared to impose tariffs on all of the roughly $\$ 500$ billion worth of imports from China. Conclusion: the US is threatening to escalate its trade war with China as a negotiating tactics.

There are several ways China could retaliate in a trade war

1. Action against US companies, by using rich variety of non-tariff trade barriers. E.g.: slowing down customs clearance for their imports, delaying or denying visa applications, or using health and safety checks.

2. Restrict tourism to the US. More than 130 million people travelled out of China in 2016. Those tourists, whose long-haul destinations included the US, spent around $\$ 260$ bn that year.

3. Devalue the currency. Lowering the value of the yuan would help exports by making Chinese goods cheaper for other countries to import, and could offset the rise in prices caused by the US tariffs.

4. Sell US bonds. China owns more than \$1tn of US government bonds, which gives Beijing influence over the US economy. There is some risk however as that would reduce the value of an asset China holds a lot of.

5. Redirect its trade and investment relations to other countries. E.g. Chinese government recently hosted EU officials and discussed free trade.

At the end of July 2018the first warning volleys by the Chinese side were fired:

- the yuan has plunged by $4.5 \%$ in value against the dollar over the previous month. It means that Chinese goods became cheaper in the U.S. and American products more expensive in China;

- Chinese investments in the U.S. in the first five months of 2018 declined 90 percent $^{15}$.

\subsection{European Union}

The trade war between the US and European Union started on March $1^{\text {st }}$, when President Trump took many by surprise by announcing that he would shortly be placing a 25 per cent tariff on steel imports and a 10 per cent tariff on aluminium. The European Commission responded by suggesting the EU could retaliate by placing tariffs on such iconic US brands like e.g. Harley Davidsons, on blue jeans,

15 Global Trade, July 30, 2018. 
Levis, on Bourbon. It is namely the E.U. Commission, which oversees trade policy for the 28 member States. As a first negotiating step (May 2018) it has announced that it may respond in three ways:

- first, to launch a legal challenge at the World Trade Organization, if possibly - jointly with other trading partners. However, as this step could take about three years for a ruling and there is no guarantee of victory,

- the second, step foreseen is that EU may consider setting safeguards in form of its own duties or quotas on imports of steel and aluminum to prevent metal shipments that might otherwise have gone to the United States;

- third, as in the EU Commission's opinion the U.S. tariffs are not to protect national security, but just the official U.S. justification and rather safeguard measures, which should only apply if imports have risen The EU can also - under WTO rules, apply similar 25 percent duties on imports from the United States to "rebalance" the situation. The Commission has already drawn up a list of products, divided into three categories - steel, agricultural products, other industrial and consumer products. The products on those lists total 6,4 billion euros, and can be applied if the WTO declared the U.S. tariffs illegal or after a period of three years.

The 28 member states had additionally agreed at a summit in Sofia in May that any deal on industrial goods with the US would come with a price tag in the form of a deal on public procurement, opening up US contracts to EU providers. In spite of such brave declarations, on July 26, 2018 the world press delivered a surprise announcement that after meeting in the White House, Donald Trump and European Commission President Jean-Claude Juncker, have informed that: ${ }^{16}$ "We agreed today, first of all, to work together towards zero tariffs, zero non-tariff barriers, and zero subsidies on non-auto industrial goods... We will also work to reduce barriers and increase trade in services, chemicals, pharmaceuticals, medical products, as well as soybeans."

According to the director of the Center for Geopolitical Studies, Eurocontinent Pierre-Emmanuelle Thomann, President of the United States Donald Trump has won a total victory over the European Union: "Everyone expected that meeting Juncker with Trump would be difficult, that eventually there would be a clash between them, but things went very well, because Juncker completely surrendered to all Trump's demands. In order to avoid duties on German production cars (Juncker - ed.), He agreed to export soy to Europe and to increase the scale of the purchase of American liquefied natural gas," said the analyst in an interview with "Sputnik". ${ }^{17}$ It seems that the situation of blackmail on the part of Trump, the European Commission is not capable of defending the interests of all members of the European Union and under

16 INDEPENDENT, July 26, 2018.

17 SPUTNIK, July 26, 2018. 
German pressure is contracting with the United States, to the detriment of interests of other EU countries - including, unfortunately, Poland.

\section{Conclusion}

It gradually turns out that the effects of the trade war caused by President Trump to invoke national security threat to justify neo-protectionism are just an official pretext. In fact, this apparent official excuse is a reflection of the decreasing role of the United States in the global economy. The United States will soon cease to be the greatest economic power in the world. It is only President Trump who is convinced that they will be able to regain this position of the economic power No. 1 through the trade war that has just been called and by undermining the current order of the global economy, based on multilateralism.

In addition, for the US economy, the effects of this trade war may turn out to be opposite than expected. They are already disclosed, among others, as:

- inflation effect: effects of Trump's tariffs are started to pop up already in reports of inflation data of the end of July 2018, and confidence indicators and in the decisions of some high-profile businesses;

- Chinese investments from the US are shifting to Europe: Chinese companies have invested a record USD 22 billion in European companies from January to June 2018. In the same period, Chinese investments in US business amounted to only $\$ 2.5$ billion, much less than a year ago.

But the bottom line is that once "Trump opens Pandora's Box by rationalizing protectionism as a national security imperative, the durability of the rules based trading system will be tested like never before, with global economic security hanging in the balance". 18

It seems however that the blackmail on the part of Trump, brings also some results. Eg. the Trump-Junker Washington meeting of July 26th, 2018 has proved that the European Commission is not capable of defending the interests of all members of the European Union. Under the German pressure is contracting with the United States, to the detriment of interests of other EU countries - including, unfortunately, Poland.

18 Ikenson, op. cit. 


\section{BIBLIOGRAPHY}

[1] Alford R.P., The Self-Judging WTO Security Exception, (2011), Journal Articles, 330. Retrieved from: https://scholarship.law.nd.edu/law_faculty_scholarship/330.

[2] BBC NEWS (online edition), Trade wars, Trump tariffs and protectionism explained, 15 June 2018. Retrieved from: https://www.bbc.com/news/world-43512098.

[3] BeaZley D., Trade-and-national-security-risks, NATIONAL, April 23, 2018, Retrieved from: http://nationalmagazine.ca/Articles/April-2018/.aspx

[4] Chang H.-J., Bad Samaritans: The Myth of Free Trade and the Secret History of Capitalism, Paperback, London 2008.

[5] Chang H-J., Kicking Away the Ladder: Development Strategy in Historical Perspective, Anthem Press, London 2002.

[6] GLOBAL TRADE, July 30, 2018.

[7] IKENSON D., (Forbes), Retrieved from: https://www.bbc.com/news/world-43512098, INDEPENDENT, July 26, 2018.

[8] Johnson H.G., Mercantilism: Past, Present and Future, „Journal of World Trade Law” 1974, No. 1, pp. 10-16.

[9] ŁaWNiczaK R., Bariery pozataryfowe: narzędzia polityki handlowej i neoprotekcjonizmu lat siedemdziesiątych, Akademia Ekonomiczna (Zeszyty Naukowe - seria II), Poznań 1975.

[10] EawniczaK R., National Economic Security Implications of Foreign Direct Investment Within the Framework of „Reverse Globalization”, „Studia Bezpieczeństwa Narodowego”, No. 4. WAT, Warszawa 2013.

[11] List F., The National System of Political Economy, J.B. Lippincott \& Co., Philadelphia 1856.

[12] Mints P., Why a Misuse of the Trade Expansion Act of 1962 Could Lead to Higher Costs for US Solar Projects, RENEWABLE ENERGY WORLD, February 27, 2018.

[13] POLITICO, July 25, 2018.

[14] SPUTNIK, July 26, 2018.

[15] Tojo J., What is neo (new) protectionism under WTO?, January 6, 2017.IndianEconomy.net. Retrieved from: https://www.indianeconomy.net/splclassroom/

[16] Yalcin E., Felbermayr G., Kinzius L., Hidden Protectionism: Non-Tariff Barriers and Implications for International Trade, ifo Institut, Munchen 2017.

\section{ZAGROŻENIE DLA BEZPIECZEŃSTWA NARODOWEGO JAKO WYMÓWKA DLA POLITYKI NEOPROTEKCJONIZMU ADMINISTRACJI PREZYDENTA TRUMPA}

Streszczenie. W marcu 2018 nowo wybrany prezydent Stanów Zjednoczonych Donald Trump zaskoczył świat, wywołując wojnę handlową ze swymi największymi partnerami handlowymi. Na początek ogłosił wprowadzenie $25 \%$ i $10 \%$ barier celnych na import stali i aluminium. W następnej kolejności zagroził objęciem cłami również importu europejskich samochodów i całej listy innych produktów, o ile partnerzy handlowi nie zaprzestaną nieuczciwych praktyk handlowych i nie obniżą własnych barier dla produktów amerykańskich. W artykule autor stara się wyjaśnić, dlaczego protekcjonistyczne posunięcia administracji amerykańskiej należy zdefiniować jako „neoprotekcjonizm” oraz dlaczego i czy słusznie oficjalne uzasadnienie podjęcia kroków protekcjonistycznych prezydent Trump uzasadnia „Zagrożeniem dla bezpieczeństwa narodowego".

Słowa kluczowe: neoprotekcjonizm, „Zagrożenie dla bezpieczeństwa narodowego”, taryfy celne, wojna handlowa. 